\title{
9-Cobalt(II)-Containing 27-Tungsto-3-germanate(IV): Synthesis, Structure, Computational Modeling, and Heterogeneous Water Oxidation Catalysis
}

\author{
Ali Haider, Bassem S. Bassil, Joaquín Soriano-Lopez, Hafiz M. Qasim, Cristina Saenz de Pipaon, \\ Masooma Ibrahim, Daipayan Dutta,Yong-Sun Koo, Jorge J. Carbo, Josep M. Poblet, \\ José Ramoń Galan-Mascaros, and Ulrich Kortz \\ Jacobs University, Department of Life Sciences and Chemistry, Campus Ring 1, 28759 Bremen, Germany \\ Department of Chemistry, Faculty of Sciences, University of Balamand, P.O. Box 100, 1300 Tripoli, Lebanon \\ Departament de Química Física i Inorganica, Universitat Rovira i Virgili, Marcel·lí Domingo 1, E-43007 Tarragona, Spain \\ Institute of Chemical Research of Catalonia (ICIQ), The Barcelona Institute of Science and Technology (BIST), Av. Països \\ Catalans 16, Tarragona E-43007, Spain
}

ICREA, Passeig Lluis Companys 23, Barcelona E-08010, Spain

* Supporting Information

ABSTRACT: The 9-cobalt(II)-containing trimeric, cyclic polyanion $\left[\mathrm{Co}_{9}(\mathrm{OH})_{3}\left(\mathrm{H}_{2} \mathrm{O}\right)_{6}\left(\mathrm{PO}_{4}\right)_{2}\left(\mathrm{~B}-\mathrm{\alpha}-\mathrm{GeW}_{9} \mathrm{O}_{34}\right)_{3}\right]^{21-}$ (1) was synthesized in an aqueous phosphate solution at $\mathrm{pH} 8$ and isolated as a hydrated mixed sodium-cesium salt. Polyanion 1 was structurally and compositionally characterized in the solid state by single-crystal X-ray diffraction, Fourier transform infrared spectroscopy, as well as thermogravimetric and elemental analyses. The magnetic and electrochemical properties of 1 were also studied and compared with those of its phosphorus analogue, $\left[\mathrm{Co}_{9}(\mathrm{OH})_{3}\left(\mathrm{H}_{2} \mathrm{O}\right)_{6}\left(\mathrm{HPO}_{4}\right)_{2}(\mathrm{~B}-\alpha-\right.$ $\left.\left.\mathrm{PW}_{9} \mathrm{O}_{34}\right)_{3}\right]^{16-}\left(\mathrm{Co}_{9}-\mathrm{P}\right)$. The electrochemical water oxidation activity of the cesium salt of 1 under heterogeneous conditions

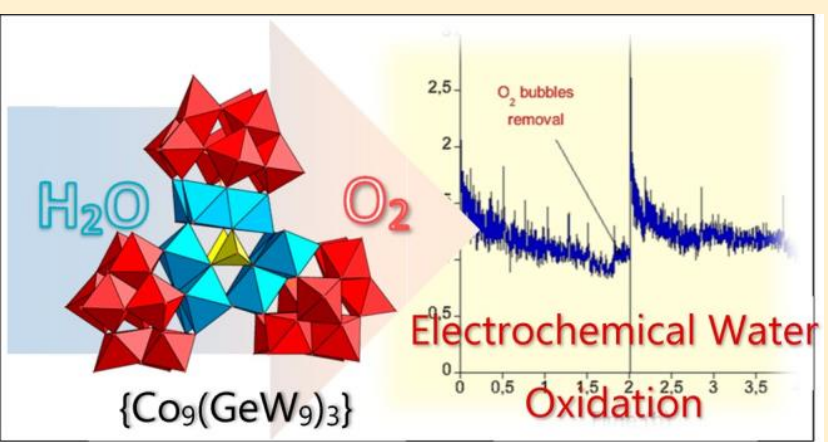
was also studied and shown to be superior to that of $\mathrm{Co}_{9}-\mathrm{P}$. The experimental results were supported by computational studies.

\section{INTRODUCTION}

Anionic, polynuclear metal-oxo molecular assemblies, commonly known as polyoxometalates (POMs), are formed by the condensation of oxoanions of early group IV and $\mathrm{V}$ transition metals such as $\mathrm{V}^{\mathrm{V}}, \mathrm{Mo}^{\mathrm{VI}}, \mathrm{W}^{\mathrm{VI}}$, etc., in their highest oxidation states. ${ }^{1}$ In a basic medium, these species form lacunary precursors that can act as inorganic ligands to stabilize transition metal cations, leading to a variety of novel POM structures. ${ }^{1}$ Due to their ample physicochemical properties, transition metal-containing POMs have potential uses in various areas such as magnetism, biomedical sciences, and catalysis. $^{2}$

Over the past 10 years, tungsten-based POMs (polyoxotungstates) containing $3 \mathrm{~d}$ and $4 \mathrm{~d}$ transition metals have been reported as promising water oxidation catalysts. ${ }^{3-5}$ To keep up with the world's growing energy demands, the development of an artificial, efficient, stable, and inexpensive homogeneous or heterogeneous water oxidation catalyst (WOC), which can mimic the natural photosynthesis process, has been of great interest. Therefore, the synthesis and design of polyoxotungstate-based WOCs with potential water oxidation activity manifested itself as a strong alternative contender to ruthenium-, iridium-, and other metal-based classical complexes. $^{3-6}$

In 2008, the Bonchio group and the Hill group separately reported the ruthenium-containing POM $\left[\left\{\mathrm{Ru}_{4} \mathrm{O}_{4}(\mathrm{OH})_{2}\left(\mathrm{H}_{2} \mathrm{O}\right)_{4}\right\}\left(\mathrm{Y}-\mathrm{SiW}_{10} \mathrm{O}_{36}\right)_{2}\right]^{10-}$ as a first example of an efficient WOC. ${ }^{3, \mathrm{~b}}$ This was followed by other $3 \mathrm{~d}$ transtion metal-containing POMs, reported as WOCs by various research groups. ${ }^{4,5}$ In particular, the activity of the cobalt-containing Weakley dimer $\left[\mathrm{Co}_{4}\left(\mathrm{H}_{2} \mathrm{O}\right)_{2}\left(\mathrm{PW}_{9} \mathrm{O}_{34}\right)_{2}\right]^{10-}$ $\left(\mathrm{Co}_{4}\right)$ was reported in 2010 by Hill and co-workers. ${ }^{4 a}$ Since then, particular consideration was given to Co-containing POMs in terms of their stability and activity as WOCs under different conditions, as either homogeneous or heterogeneous (embedded over a support) catalysts. ${ }^{4}$

Of special interest is the nonacobalt-containing, phosphates t abilized t ung tophosphat e $\mathrm{trimer}$ $\left[\mathrm{Co}_{9}\left(\mathrm{H}_{2} \mathrm{O}\right)_{6}(\mathrm{OH})_{3}\left(\mathrm{HPO}_{4}\right)_{2}\left(\mathrm{~B}-\alpha-\mathrm{PW}_{9} \mathrm{O}_{34}\right)_{3}\right]^{16-} \quad\left(\mathrm{Co}_{9}-\mathrm{P}\right)$, which was first identified by Weakley in $1984^{7 \mathrm{a}}$ and reinvestigated by Coronado and co-workers in $1994 .^{7 \mathrm{~b}, \mathrm{c}}$ The 
group of Galan-Mascaros has demonstrated that $\mathrm{Co}_{9}-\mathrm{P}$ is an effective homogeneous and heterogeneous catalyst for water oxidation, with significant long-term stability and remarkable activity even in acid media, surpassing the performance of noble metal catalysts at $\mathrm{pH}<1$. ${ }^{4 \mathrm{k}, \mathrm{k}, \mathrm{v}}$ Herein, we report the synthesis and characterization of its tungstogermanate analogue $\left[\mathrm{Co}_{9}(\mathrm{OH})_{3}\left(\mathrm{H}_{2} \mathrm{O}\right)_{6}\left(\mathrm{PO}_{4}\right)_{2}\left(\mathrm{~B}-\alpha-\mathrm{GeW}_{9} \mathrm{O}_{34}\right)_{3}\right]^{21-} \quad$ (1) as a potential WOC. Compound 1 was isolated as a hydrated mixed sodium-cesium salt $\mathrm{Na}_{15.5} \mathrm{Cs}_{5.5}\left[\mathrm{Co}_{9}(\mathrm{OH})_{3}\right.$ $\left.\left(\mathrm{H}_{2} \mathrm{O}\right)_{6}\left(\mathrm{PO}_{4}\right)_{2}\left(\mathrm{~B}-\alpha-\mathrm{GeW}_{9} \mathrm{O}_{34}\right)_{3}\right] \cdot 65 \mathrm{H}_{2} \mathrm{O}$ (NaCs-1), which was characterized in the solid state by single-crystal $\mathrm{X}$-ray diffraction, infrared spectroscopy, thermogravimetric and elemental analyses, and magnetic measurements. The electrocatalytic properties of 1 have been analyzed and compared with those of $\mathrm{Co}_{9}-\mathrm{P}$ to determine the effect of $\mathrm{Ge}$ (IV) substitution. This study was supported by computational calculations, confirming the positive effect upon heteroatom substitution.

\section{EXPERIMENTAL SECTION}

Materials and Physical Measurements. The precursor salt $\mathrm{Na}_{10}\left[\mathrm{~A}-\alpha-\mathrm{GeW}_{9} \mathrm{O}_{34}\right] \cdot 23 \mathrm{H}_{2} \mathrm{O}$ was prepared according to a published procedure and characterized by Fourier transform infrared (FT-IR) spectroscopy. ${ }^{8}$ All other reagents were used as purchased without further purification. Infrared spectra were recorded on a Nicolet Avatar 370 FT-IR spectrophotometer using $\mathrm{KBr}$ pellets. The following abbreviations were used to assign peak intensities: w, weak; m, medium; s, strong. Thermogravimetric analysis was carried out on a TA Instruments SDT Q600 thermobalance with a $100 \mathrm{~mL} / \mathrm{min}$ flow of nitrogen; the temperature was increased from room temperature to $500{ }^{\circ} \mathrm{C}$ at a rate of $5{ }^{\circ} \mathrm{C} / \mathrm{min}$. Elemental analysis was performed by CNRS, Service Central d'Analyze, Solaize, France.

Synthesis of $\mathrm{Na}_{15}{ }_{5} \mathrm{Cs}_{5.5}\left[\mathrm{Co}_{9}(\mathrm{OH})_{3}\left(\mathrm{H}_{2} \mathrm{O}\right)_{6}\left(\mathrm{PO}_{4}\right)_{2}(\mathrm{~B}-\alpha-\right.$ $\left.\left.\mathrm{GeW}_{9} \mathrm{O}_{34}\right)_{3}\right] \cdot 65 \mathrm{H}_{2} \mathrm{O}$ (NaCs-1). To a solution of $0.13 \mathrm{~g}(0.60$ $\mathrm{mmol})$ of $\mathrm{CoCl}_{2} \cdot 6 \mathrm{H}_{2} \mathrm{O}$ in $20 \mathrm{~mL}$ of $\mathrm{H}_{2} \mathrm{O}$ was added $0.50 \mathrm{~g}(0.20$ mmol) of $\mathrm{Na}_{9}\left[\mathrm{~A}-\alpha-\mathrm{GeW}_{9} \mathrm{O}_{34}\right] \cdot 18 \mathrm{H}_{2} \mathrm{O}$, and the mixture was stirred until a clear, purple solution was obtained. Then, $0.50 \mathrm{~g}(3.0 \mathrm{mmol})$ of $\mathrm{Na}_{3} \mathrm{PO}_{4}$ was added in small portions while the $\mathrm{pH}$ value was held at 8 with a $1 \mathrm{M}$ aqueous $\mathrm{HCl}$ solution. The resulting turbid solution was stirred for $1 \mathrm{~h}$ at $70^{\circ} \mathrm{C}$ and became clear during heating. The solution was then allowed to cool and then filtered. After a day, purple crystals of the known polyanion $\left[\left\{\mathrm{Co}_{4}(\mathrm{OH})_{3} \mathrm{PO}_{4}\right\}_{4}\left(\mathrm{~A}-\alpha-\mathrm{GeW}_{9} \mathrm{O}_{34}\right)_{4}\right]^{32-}$ $\left(\mathrm{Co}_{16}\right)$ were obtained. ${ }^{9}$ The solution was filtered, and $2-3$ drops of 1.0 M CsCl were added to the filtrate. The solution was kept in an open vial at room temperature to allow slow evaporation. After 1 week, a purple, needle-shaped crystalline product started to appear, which was then collected by filtration and air-dried. Yield: $80 \mathrm{mg}$ (22\%). IR data ( $\mathrm{KBr}$ pellet) in $\mathrm{cm}^{-1}: 1059(\mathrm{~m}), 935(\mathrm{~m}), 880(\mathrm{~m})$, 764(m), 701(w), 450(w) (Figure S1). Elemental analysis (\%) for $\mathrm{Cs}_{5}{ }_{5} \mathrm{Na}_{15.5}\left[\mathrm{Co}_{9}(\mathrm{OH})_{3}\left(\mathrm{H}_{2} \mathrm{O}\right)_{6}\left(\mathrm{PO}_{4}\right)_{2}\left(\mathrm{~B}-\alpha-\mathrm{GeW}_{9} \mathrm{O}_{34}\right)_{3}\right] \cdot 65 \mathrm{H}_{2} \mathrm{O}$. Calcd (found): Na, 3.58 (3.64); P, 0.62 (0.61); Co, 5.33 (5.42); Ge, 2.20 (2.26); Cs, 7.35 (7.46); W, 49.9 (48.9)

Preparation of $\mathrm{Cs}_{21}\left[\mathrm{Co}_{9}(\mathrm{OH})_{3}\left(\mathrm{H}_{2} \mathrm{O}\right)_{6}\left(\mathrm{PO}_{4}\right)_{2}\left(\mathrm{~B}-\mathrm{\alpha}-\mathrm{GeW}_{9} \mathrm{O}_{34}\right)_{3}\right]$. $38 \mathrm{H}_{2} \mathrm{O}$ (Cs-1). To a solution of $0.20 \mathrm{~g}$ of NaCs-1 in $20 \mathrm{~mL}$ of $\mathrm{H}_{2} \mathrm{O}$ was slowly added solid $\mathrm{CsCl}$ while the mixture was being stirred, until the complete precipitation of Cs-1 in the form of a pink solid, leaving the solution colorless. This solid was filtered, washed first with water and next with acetone, and then air-dried. Yield: $222 \mathrm{mg}(98 \%)$. The IR spectra of Cs-1 and NaCs-1 are identical (see Figure S1, showing both IR spectra). The complete substitution of the $\mathrm{Na}^{+}$by $\mathrm{Cs}^{+}$counter cations was confirmed by EDX analysis of the as-prepared powder.

X-ray Crystallography. A single crystal of NaCs-1 was mounted on a Hampton cryoloop in light oil for data collection at $100 \mathrm{~K}$. A Bruker D8 SMART APEX II CCD diffractometer with $\mathrm{K}$ geometry and Mo Ka radiation (graphite monochromator; $\lambda=0.71073 \AA$ ) was used for indexing and data collection. Data integration was performed using SAINT, ${ }^{10}$ and routine Lorentz and polarization corrections were applied. Multiscan absorption corrections were performed using SADABS. ${ }^{11,12}$ Direct methods (SHELXS97) successfully located the tungsten atoms, and successive Fourier syntheses (SHELXL2013) revealed the remaining atoms. ${ }^{13}$ Refinements were full-matrix least squares against $\left|F^{2}\right|$ using all data. In the final refinement, all nondisordered heavy atoms ( $\mathrm{Na}, \mathrm{Cs}, \mathrm{P}, \mathrm{Co}, \mathrm{Ge}$, and $\mathrm{W})$ were refined anisotropically; oxygen atoms and disordered counter cations were refined isotropically. No hydrogen atoms were included in the models. For the sake of overall consistency, the same formula unit is shown in the CIF file and in the text, with the same number of counter cations and crystal waters, as based on elemental analysis, because such formula unit reflects the true composition of the bulk material. Crystallographic data are summarized in Table 1. Further details

\begin{tabular}{|c|c|}
\hline empirical formula & $\mathrm{H}_{145} \mathrm{Co}_{9} \mathrm{Cs}_{5.5} \mathrm{Ge}_{3} \mathrm{Na}_{15.5} \mathrm{O}_{184} \mathrm{P}_{2} \mathrm{~W}_{27}$ \\
\hline formula weight $(\mathrm{g} / \mathrm{mol})$ & 9951.21 \\
\hline crystal system & triclinic \\
\hline space group & $\mathrm{P} \overline{1}$ \\
\hline$a(\AA)$ & $19.8452(15)$ \\
\hline$b(\AA)$ & $21.4862(15)$ \\
\hline$c(\AA)$ & $21.5069(15)$ \\
\hline$\alpha(\operatorname{deg})$ & $91.465(3)$ \\
\hline$\beta(\operatorname{deg})$ & $112.489(3) \mathrm{V}$ \\
\hline$(\mathrm{deg})$ & $94.604(4)$ \\
\hline volume $\left(\AA^{3}\right)$ & $8429.99(107)$ \\
\hline Z & 2 \\
\hline $\mathrm{D}_{\text {calc }}\left(\mathrm{g} / \mathrm{cm}^{3}\right)$ & 3.10057 \\
\hline absorption coefficient $\left(\mathrm{mm}^{-1}\right)$ & 21.080 \\
\hline$F(000)$ & 8914 \\
\hline crystal size $\left(\mathrm{mm}^{3}\right)$ & $0.45 \times 0.163 \times 0.087$ \\
\hline$\theta$ range for data collection (deg) & $3.400-20.815$ \\
\hline no. of reflections collected & 231645 \\
\hline no. of independent reflections & 17392 \\
\hline $\mathrm{R}$ (int) & 0.1207 \\
\hline observed $[\mathrm{I}>2 \sigma(\mathrm{I})]$ & 12150 \\
\hline goodness of fit on $\mathrm{F}^{2}$ & 1.006 \\
\hline $\mathrm{R}_{1}[\mathrm{I}>2 \sigma(\mathrm{I})]^{\mathrm{a}}$ & 0.0721 \\
\hline $\mathrm{wR}_{2}$ (all data) ${ }^{\mathrm{b}}$ & 0.1652 \\
\hline
\end{tabular}

about the crystal structure investigation may be obtained from the Cambridge Structural Database (https://www.ccdc.cam.ac.uk/ structures/), on quoting the depository number CSD 1916667

Magnetic Susceptibility Measurements. Magnetic susceptibility measurements between 2 and $300 \mathrm{~K}$ were carried out on a polycrystalline sample with a Quantum Design MPMS-XL SQUID magnetometer using a 1000 Oe field. Pascal's constants were used to estimate the diamagnetic corrections for the compounds. Magnetization curves were collected between -7 and $7 \mathrm{~T}$ at 2 and $10 \mathrm{~K}$.

Electrochemical Measurements. All experiments were performed with a Biologic SP-150 potentiostat. Ohmic drop was compensated for using the positive feedback compensation implemented in the instrument. For cyclic voltammetry experiments, an amorphous carbon paste working electrode $\left(0.07 \mathrm{~cm}^{2}\right)$, a Pt wire counter electrode, and a $\mathrm{Ag} / \mathrm{AgCl}(\mathrm{NaCl} 3.5 \mathrm{M})$ reference electrode were placed in a beaker with a $\mathrm{pH} 7$ sodium phosphate $\left(\mathrm{NaP}_{\mathrm{i}}\right)$ buffer solution $(50 \mathrm{mM})$ and $\mathrm{NaNO}_{3}(1 \mathrm{M})$ as the electrolyte. The carbon paste mixtures were prepared in a mortar by mixing amorphous carbon paste (Biologic Carbon paste oil base) and Cs- 1 in the desired proportion. Bulk water electrolysis and steady-state experiments were carried out with stirring in a two-chamber cell, with a porous frit connecting both chambers. In one chamber, we placed a Pt mesh counter electrode, and in the other chamber, we placed the modified carbon paste working electrode $\left(0.07 \mathrm{~cm}^{2}\right)$ and the reference electrode. Typical electrolysis experiments were carried out in a $\mathrm{pH}$ 
$7 \mathrm{NaP}_{\mathrm{i}}(50 \mathrm{mM})$ buffer solution with $\mathrm{NaNO}_{3}\left(\begin{array}{ll}1 & \mathrm{M}\end{array}\right)$ as the electrolyte.

Computational Methods. All reported calculations were performed with the Gaussian-09 package $^{14}$ at the density functional theory (DFT) level by utilizing the B3LYP functional. ${ }^{15}$

For $\mathrm{Co}, \mathrm{W}, \mathrm{Ge}$, and $\mathrm{P}$ atoms, the LANL2DZ effective core potential (ECP) and associated basis sets were used. ${ }^{16}$ The 6$31 \mathrm{G}(\mathrm{d}, \mathrm{p})$ basis set was used for $\mathrm{O}$ atoms directly bound to $\mathrm{Co}$, and the $6-31 \mathrm{G}$ basis set for the rest of atoms. ${ }^{17}$ All of the structures were optimized in water using the IEF-PCM approach to model the water solvent effects $\left(\varepsilon=78.36\right.$ and UFF radii). ${ }^{18}$ The nature of all stationary points was verified by vibrational frequencies. A data set collection of computational results is available in the ioChem-BD repository $^{19}$ and can be accessed via https://doi.org/10.19061/ iochem-bd-2-25.

\section{RESULTS AND DISCUSSION}

Synthesis and Structure. Polyanion 1 is a byproduct during the synthesis of our reported $16-\mathrm{Co}^{\mathrm{II}}$-containing $\left[\left\{\mathrm{Co}_{4}(\mathrm{OH})_{3} \mathrm{PO}_{4}\right\}_{4}\left(\mathrm{~A}-\alpha-\mathrm{GeW}_{9} \mathrm{O}_{34}\right)_{4}\right]^{32-}\left(\mathrm{Co}_{16}\right)^{9}$. After the

formation of $\mathrm{Co}_{16}$ and filtration of the solution, needle-like crystals of 1 were isolated as a hydrated sodium-cesium salt $\mathrm{Na}_{15.5} \mathrm{Cs}_{5.5}\left[\mathrm{Co}_{9}(\mathrm{OH})_{3}\left(\mathrm{H}_{2} \mathrm{O}\right)_{6}\left(\mathrm{PO}_{4}\right)_{2}\left(\mathrm{~B}-\alpha-\mathrm{GeW}_{9} \mathrm{O}_{34}\right)_{3}\right]$. $65 \mathrm{H}_{2} \mathrm{O}(\mathrm{NaCs}-1)$ a week after the addition of $1 \mathrm{~mL}$ of a $1 \mathrm{M}$ $\mathrm{CsCl}$ solution to the filtrate. It is worth noting here that Weakley's $\mathrm{Co}_{9}-\mathrm{P}$ is also a byproduct during the synthesis of $\left[\mathrm{Co}_{4}\left(\mathrm{H}_{2} \mathrm{O}\right)_{2}\left(\mathrm{PW}_{9} \mathrm{O}_{34}\right)_{2}\right]^{10-}$ and was crystallized after the addition of a second type of alkaline ion. ${ }^{7 \mathrm{a}}$ The FT-IR spectra (Figure S2) of $\mathrm{Co}_{16}$ and NaCs-1 clearly showed two different structural species. Single-crystal X-ray diffraction analysis revealed that $\mathrm{NaCs}-1$ crystallized in the $\mathrm{P}^{\overline{1}}$ space group (see Table 1). The structure of polyanion 1 is identical to that of Weakley's reported tungstophosphate analogue $\left[\mathrm{Co}_{9}\left(\mathrm{H}_{2} \mathrm{O}\right)_{6}(\mathrm{OH})_{3}\left(\mathrm{HPO}_{4}\right)_{2}\left(\mathrm{~B}-\alpha-\mathrm{PW}_{9} \mathrm{O}_{34}\right)_{3}\right]^{16-}\left(\mathrm{Co}_{9}-\mathrm{P}\right)^{7 \mathrm{a}}$ and comprises an inner $\left[\mathrm{Co}_{9}\left(\mathrm{H}_{2} \mathrm{O}\right)_{6}(\mathrm{OH})_{3}\left(\mathrm{PO}_{4}\right)_{2}\right]^{9+}$ core of three $\left\{\mathrm{Co}_{3}\right\}$ "triads" bridged to each by hydroxo linkages (Figure 1), with two phosphate groups capping the assembly
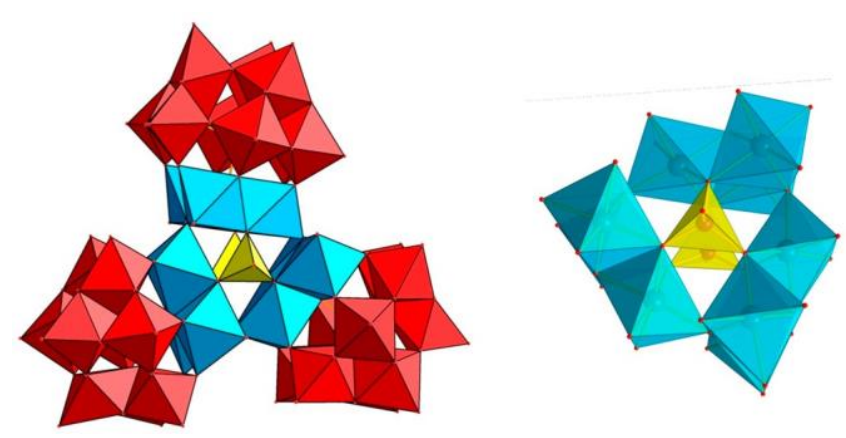

Figure 1. Polyhedral representation of polyanion 1 (left) and the $\left[\mathrm{Co}_{9}\left(\mathrm{H}_{2} \mathrm{O}\right)_{6}(\mathrm{OH})_{3}\left(\mathrm{PO}_{4}\right)_{2}\right]^{9+}$ core (right) $\left(\mathrm{WO}_{6}\right.$, red; $\mathrm{CoO}_{6}$, turquoise; $\mathrm{HPO}_{4}$, yellow).

from opposite sides. Each $\left\{\mathrm{Co}_{3}\right\}$ triad fills the lacunary position of one $\left\{B-\alpha-\mathrm{GeW}_{9}\right\}$ unit. In other words, the structure can also be viewed as a triangular assembly of three $\left\{\mathrm{Co}_{3}(\mathrm{~B}-\alpha-\right.$ $\mathrm{GeW}_{9}$ ) units connected to each other by three hydroxo groups and capped by two phosphate groups (Figure 1). Bond valence sum (BVS) calculations ${ }^{20}$ (Table S1) indicated that the bridging oxygen atoms among the three $\left\{\mathrm{Co}_{3}\left(\mathrm{~B}-\alpha-\mathrm{GeW}_{9}\right)\right\}$ units are protonated and that all terminal ligands on the cobalt centers are aqua. No further protonation within the POM assembly was however found by BVS. It is worth noting that the reported tungstophosphate analogue of $1, \mathrm{Co}_{9}-\mathrm{P}$, had additional protonation sites on the terminal oxo ligands of the phosphate capping groups, whereas for 1, the same sites are nonprotonated. This difference in phosphate protonation is mainly due to the difference in the starting material and synthesis procedure. Weakley's $\mathrm{Co}_{9}-\mathrm{P}$ is synthesized starting with $\mathrm{HPO}_{4}{ }^{2-}$ at $\mathrm{pH}$ 7.0, whereas our polyanion 1 is synthesized using $\mathrm{PO}_{4}{ }^{3-}$ at $\mathrm{pH}$ 8.0. In the solid state, all cobalt centers in 1 exhibit a distorted octahedral geometry, with $\mathrm{Co}^{\mathrm{II}}-\mathrm{O}$ bond lengths and $\mathrm{O}-\mathrm{Co}^{\mathrm{II}}-\mathrm{O}$ angles falling in the respective ranges of $2.01(2)-2.17(3) \AA$ and $81.9(9)-$ $96.9(10)^{\circ}$, respectively. The chemical composition of NaCs1 was further confirmed by thermogravimetric (Figure S3) and elemental analysis (Experimental Section).

The key for synthesizing 1 and isolating it cleanly free of $\mathrm{Co}_{16}$ lies in the synthesis of the $\mathrm{Na}_{10}\left[\mathrm{~A}-\alpha-\mathrm{GeW}_{9} \mathrm{O}_{34}\right] \cdot 18 \mathrm{H}_{2} \mathrm{O}$ precursor salt. The synthesis of 1 must be performed using the crude POM precursor salt which has been precipitated with a saturated solution of $\mathrm{NaCO}$, according to Herve and Teze. ${ }^{8}$ We discovered that using the unwashed POM precursor (see Figure S4 for the differences in the IR spectra of the washed and unwashed POM precursors) was crucial for the isolation of clean 1 . An attempt to synthesize 1 using the POM precursor washed with a $4 \mathrm{M} \mathrm{NaCl}$ solution led to the isolation of $\mathrm{Co}_{16}$ in high yield without any 1 . Moreover, attempts to prepare 1 by simply adding solid $\mathrm{Na}_{2} \mathrm{CO}_{3}$ and $\mathrm{Na}_{3} \mathrm{PO}_{4}$ during the synthesis were unsuccessful. Finally, the crystallization of 1 required the presence of cesium counter cations in addition to the sodium cations already present in solution. We speculate that a solution equilibrium exists between 1 and $\mathrm{Co}_{16}$ and that the type of counter cation(s) present in solution determines which POM salt will crystallize, either 1 as a mixed sodium-cesium salt or $\mathrm{Co}_{16}$ as a sodium-only salt.

Magnetic Characterization. The magnetic properties of polyanion 1 are dominated by the strong magnetic anisotropy of octahedral high-spin Co ${ }^{I I}$ cations. The product of the magnetic molar susceptibility times the temperature $\left(X_{m} T\right)$ at room temperature is significantly higher than the spin-only expected value for magnetically diluted $S=3 / 2$ centers: $X_{\mathrm{m}} \mathrm{T}=$

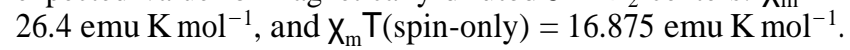
When the temperature is decreased, $X_{m} \top$ shows a continuous decrease, which can be attributed to the single-ion anisotropy but also suggests the presence of dominant antiferromagnetic exchange interactions. Due to the high magnetic nuclearity of this cluster, a rigorous treatment is unavailable in this case and some justified assumptions need to be taken into account. (1) Only super exchange interactions through oxo bridges will be taken into account, assuming as negligible the exchange pathways through $\mathrm{PO}_{4}{ }^{3-}$ groups. (2) A fully anisotropic Ising model has been assumed for the $\mathrm{Co}-\mathrm{Co}$ exchange interaction, in agreement with the large spin anisotropy exhibited by highspin cobalt(II) with an octahedral coordination. This assumption limits the applicability of the model to the lowtemperature range ( $\mathrm{T}<30 \mathrm{~K}$ ), where only the lowest-lying Kramers doublet of $\mathrm{Co}(\mathrm{II})$ is significantly populated. This model is adequate for obtaining useful information about the exchange interactions. The resulting exchange Hamiltonian can be written as

$$
\begin{aligned}
H & =-2 J\left(S_{1 z} S_{2 z}+S_{1 z} S_{3 z}+S_{2 z} S_{3 z}+S_{4 z} S_{5 z}+S_{4 z} S_{6 z}+S_{5 z} S_{6 z}\right. \\
& \left.+S_{7 z} S_{8 z}+S_{7 z} S_{9 z}+S_{8 z} S_{9 z}\right)-2 J^{\prime}\left(S_{1 z} S_{8 z}+S_{1 z} S_{9 z}+S_{2 z} S_{4 z}\right. \\
& \left.+S_{3 z} S_{4 z}+S_{5 z} S_{7 z}+S_{6 z} S_{7 z}\right)
\end{aligned}
$$



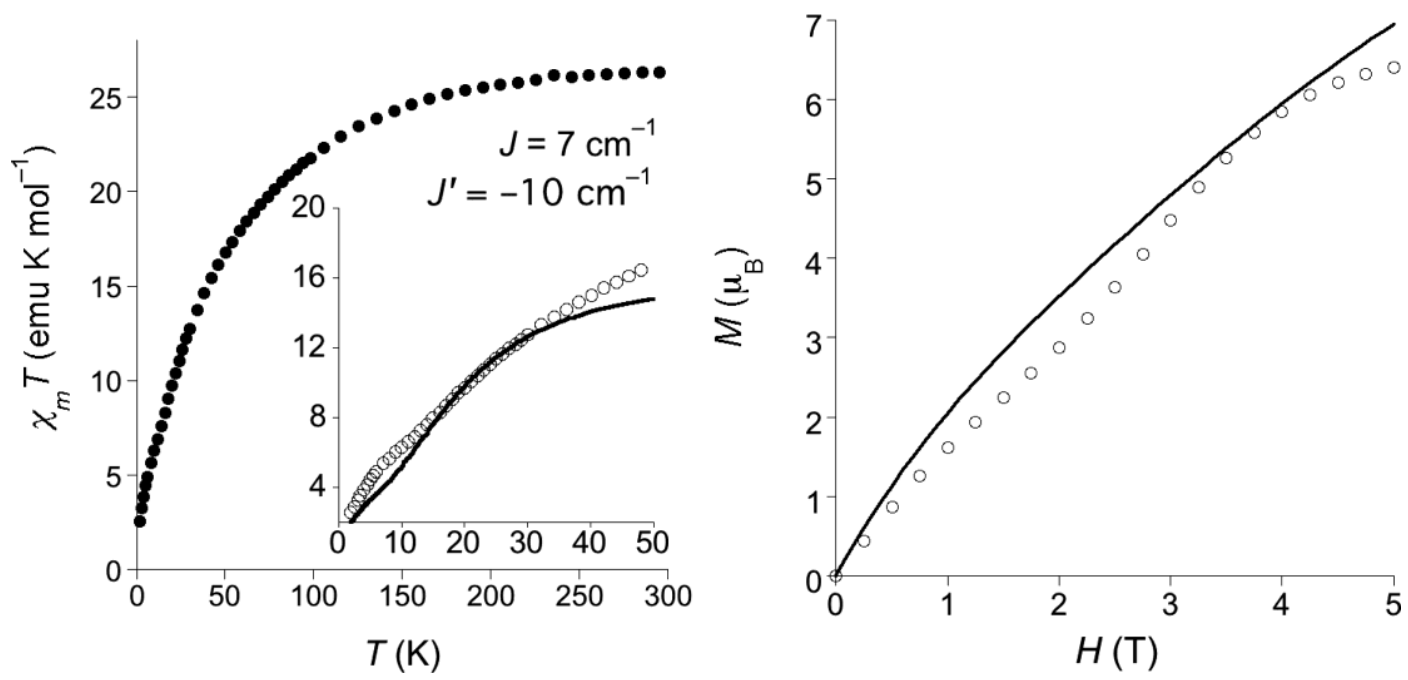

Figure 2. Magnetic behavior of NaCs-1. Evolution of the $\mathrm{X}_{\mathrm{m}} \mathrm{T}$ product as a function of temperature (left). Magnetization as a function of magnetic field (right). In both plots, the solid line represents the best fit from the Ising model as described in the text.

where $J$ and $J^{\prime}$ correspond to the two types of pairwise superexchange interactions present in the cluster (intra and inter-triangles, respectively) and $S$ is the spin operator ( $z$ component) associated with the effective spin $S=1 / 2$ of atom i. The numbering of the atoms is given in the exchange network (see Scheme S1).

A set of parameters that better model the experimental data are as follows: $\mathrm{g}=4.4, \mathrm{~J}=7 \mathrm{~cm}^{-1}$, and $\mathrm{J}^{\prime}=-10 \mathrm{~cm}^{-1}$ (Figure 2) These parameters can reproduce both, the thermal dependence of the magnetic susceptibility and the field dependence of the magnetization, confirming the solidity of the model. The different sign of the exchange interactions correlates well with the structural features of the cluster. Edgesharing octahedra with $\mathrm{Co}-\mathrm{O}-\mathrm{Co}$ angles in the range of 90$100^{\circ}$ favor the orthogonality of the magnetic orbitals and therefore ferromagnetic coupling. Conversely, for the interactions through corner-sharing octahedra, these angles are larger $\left(\sim 120^{\circ}\right)$ and the antiferromagnetic exchange pathways become dominant. It is worth mentioning that these parameters are very close to those reported for the isostructural $\mathrm{Co}_{9}-\mathrm{P}\left(\mathrm{J}=8.4\right.$, and $\left.\mathrm{J}^{\prime}=-12 \mathrm{~cm}^{-1}\right){ }^{7 \mathrm{~b}}$ Therefore, the substitution of $\mathrm{P}$ by Ge does not significantly affect the magnetic properties of the polyoxoanion, and it can be concluded that the oxidation state of Co centers stays as $\mathrm{Co}^{\mathrm{II}}$ in all cases.

Heterogeneous Water Oxidation Catalysis. To compare the catalytic activity of 1 with that of the related $\mathrm{Co}_{9}-\mathrm{P}$, we decided to carry out such assays under heterogeneous conditions, where POMs are stable and robust. On the contrary, homogeneous conditions present many problems due to adventitious formation of minor traces of $\mathrm{CoO}_{\mathrm{x}}{ }^{4 \mathrm{~d}, \mathrm{~m}, \mathrm{r}}$ which preclude proper characterization. This is not the case in the solid state.

The insoluble salt Cs-1 was obtained by metathesis by addition of an excess of $\mathrm{CsCl}$ to a NaCs-1 aqueous solution, following the literature procedure. ${ }^{4 \mathrm{k}}$ This solid was filtered and dried in air to be blended with carbon paste. Carbon paste blends with POM contents between 5 and $35 \%$ in weight were prepared as modified carbon paste electrodes (Cs-1/CP). Cyclic voltammetry with $\mathrm{Cs}-1 / \mathrm{CP}$ working electrodes shows a strong oxidation wave that is absent for the pure $\mathrm{CP}$ electrode under the same conditions, suggesting the participation of a catalytic process promoted by the Co-POM component (Figure S5). During successive cycles, oxygen bubbles appeared on the electrode, and an oxygen reduction wave was detected below $-0.3 \mathrm{~V}$, confirming oxygen evolution.

The kinetics of the modified Cs-1/CP electrodes were studied by steady-state current experiments. These data allowed the construction of Tafel plots (Figure 3) as a

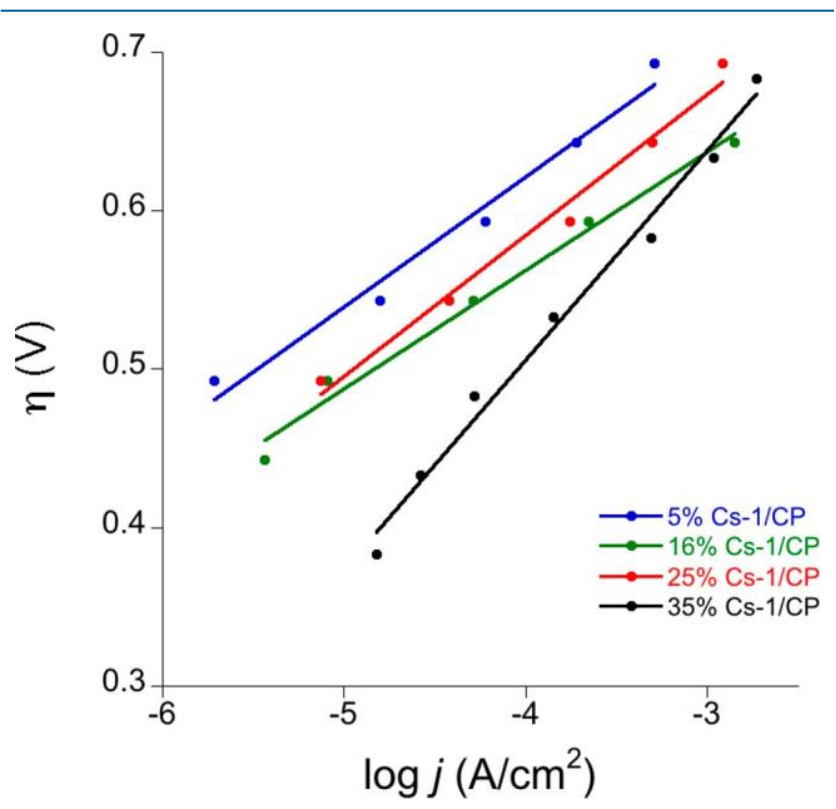

Figure 3. Tafel plot from the steady-state data acquired with a $\mathrm{pH} 7$ $\mathrm{NaP}_{\mathrm{i}}(50 \mathrm{mM})$ buffer with $\mathrm{NaNO}_{3}(1 \mathrm{M})$ as the electrolyte, for different $\mathrm{Cs}-1 / \mathrm{CP}$ ratios by weight.

function of POM content. Current densities (j) obtained with catalyst contents between $5 \%$ and $30 \%$ in weight showed electrocatalytic features, with consistent Tafel slopes in the range of $75-90 \mathrm{mV} / \mathrm{dec}$ ade. Above this threshold, the Tafel slope increases to $130 \mathrm{mV} /$ decade, indicating a different ratelimiting process, maybe due to mass transport issues. The best kinetics were found for modified $\mathrm{Cs}-1 / \mathrm{CP}$ electrodes with a $16 \%$ content of Cs-1, where the slope reached the minimum value and the current densities were maximized. 
Bulk water electrolysis was carried out in a two-chamber cell separated by a glass frit, in a pH $7 \mathrm{NaP}_{\mathrm{i}}(50 \mathrm{mM})$ buffer solution with $\mathrm{NaNO}_{3}(1 \mathrm{M})$ as the electrolyte. As shown in Figure 4, Cs-1/CP working electrodes show a remarkably

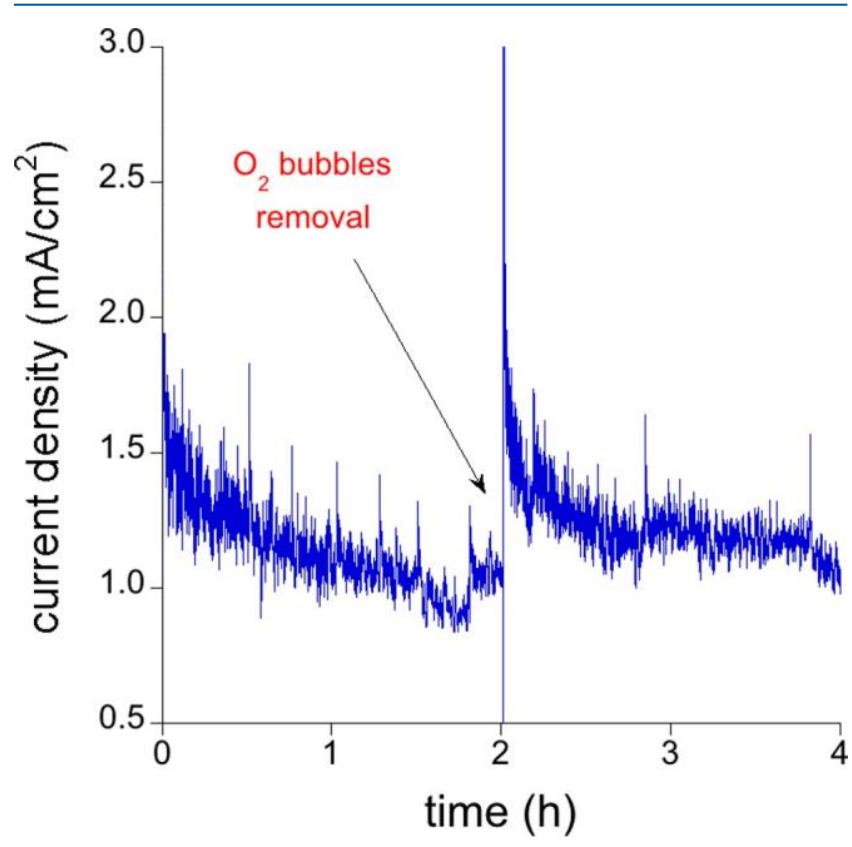

Figure 4. Current density at $1.5 \mathrm{~V}$ vs NHE $(\eta=0.68 \mathrm{~V})$ with a $25 \%$ Cs-1/CP modified electrode in a $\mathrm{pH} 7 \mathrm{NaP}_{\mathrm{i}}(50 \mathrm{mM})$ buffer with $\mathrm{NaNO}_{3}(1 \mathrm{M})$ as the electrolyte.

stable performance. Although $\mathrm{j}$ decreases slowly during the first hours, this effect must be attributed to the accumulation of $\mathrm{O}_{2}$ gas bubbles trapped on the carbon paste electrode surface, thus leading to a decrease in the active surface area. Indeed, the initial values of current density were recovered by removal of the $\mathrm{O}_{2}$ bubbles after bulk water electrolysis for $2 \mathrm{~h}$, at a current density above $1 \mathrm{~mA} / \mathrm{cm}^{2}$ at $1.5 \mathrm{~V}$ versus NHE. This observation is not compatible with catalyst deactivation.

To investigate the stability of Cs-1 under turnover conditions, the POM was recovered from the blend. The characterization of the recovered catalyst shows features identical to those observed for the freshly made Cs-1 (Figures S6 and S7), without any new features that could be assigned to $\mathrm{CoO}_{x}$, a common and catalytically active decomposition product of Co-POMs. The recovery from the blend is nonquantitative, so we cannot neglect the presence of additional decomposition compounds. However, such compounds should appear as traces, because they were undetectable in the recovered bulk. It is worth noting that although $\mathrm{CoO}_{\mathrm{x}}$ is $10-100$ times more active than the corresponding Co-POMs when in solution, ${ }^{21}$ this is not the case for carbon paste electrodes, where quantitative decomposition of the Co-POM could not account for the observed activity. $^{4 \mathrm{k}}$

Substitution of the heteroatom in POM structures may have significant effects on their catalytic performance. ${ }^{4 p}$ Thus, it is of interest to compare the activity of 1 with that of the analogous "all-phosphate" derivative, $\mathrm{Co}_{9}-\mathrm{P}$. Cs-1 and $\mathrm{Cs}_{15} \mathrm{~K}$ $\left[\mathrm{Co}_{9}\left(\mathrm{H}_{2} \mathrm{O}\right)_{6}(\mathrm{OH})_{3}\left(\mathrm{HPO}_{4}\right)_{2}\left(\mathrm{PW}_{9} \mathrm{O}_{34}\right)_{3}\right] \cdot 41 \mathrm{H}_{2} \mathrm{O} \quad\left(\mathrm{Cs}^{-} \mathrm{Co}_{9}-\mathrm{P}\right)$ yield analogous Tafel slopes (Figure $\mathrm{S} 8$ ), beyond experimental error, which suggests that the rate-limiting step is the same for both POMs. This supports the idea that both catalysts are following the same reaction pathway toward water oxidation, as expected from the identical geometry of their active sites. In the potential range studied, Cs-1 shows overall higher current densities at the same overpotentials, suggesting an intrinsic superior electrocatalytic activity

Computational Analysis of the Electronic Structure: The Effect of the Heteroatom. DFT has been extensively used to study the electronic properties, structure, and reactivity of polyoxometalates. ${ }^{22}$ Here, we analyze the electronic structure of polyanion 1 and compare it with its structurally analogous phosphorus derivative $\mathrm{Co}_{9}-\mathrm{P}$ in their resting states. Unfortunately, 1 and $\mathrm{Co}_{9}-\mathrm{P}$ are large polyoxometalates in which all nine Co atoms are in their +2 oxidation state, with a formal $\mathrm{d}^{7}$ high-spin configuration. This results in a complex electronic structure with 27 unpaired electrons. Given that the energies of the frontier molecular orbitals do not change too much when we replace three $\mathrm{Co}^{2+}$ ions with three $\mathrm{Zn}^{2+}$ ions in the well-known Weakley-type sandwich ion $\left[\mathrm{Co}_{4}\left(\mathrm{H}_{2} \mathrm{O}\right)_{2}\left(\mathrm{PW}_{9} \mathrm{O}_{34}\right)_{2}\right]^{10-}$ (Table S2), we decided to simplify the electronic structure by replacing eight of the $\mathrm{Co}^{2+}$ atoms with eight $\mathrm{Zn}^{2+}$ atoms, yielding the polyanions $\left[\mathrm{Co}\left(\mathrm{H}_{2} \mathrm{O}\right)\right.$ $\left.\mathrm{Zn}_{8}\left(\mathrm{H}_{2} \mathrm{O}\right)_{5}(\mathrm{OH})_{3}\left(\mathrm{HPO}_{4}\right)_{2}\left(\mathrm{PW}_{9} \mathrm{O}_{34}\right)_{3}\right]^{16-}(\mathrm{CoP})$ and $[\mathrm{Co}-$ $\left.\left(\mathrm{H}_{2} \mathrm{O}\right) \mathrm{Zn}_{8}\left(\mathrm{H}_{2} \mathrm{O}\right)_{5}(\mathrm{OH})_{3}\left(\mathrm{PO}_{4}\right)_{2}\left(\mathrm{GeW}_{9} \mathrm{O}_{34}\right)_{3}\right]^{21-} \quad(\mathrm{CoGe})$. The resulting complex can be regarded as a single-site cobalt water oxidation catalyst with three unpaired electrons. This simplified model still requires a strong computational effort but is affordable with DFT methods. Moreover, we have constrained the rotation of the water molecule linked to the Co atom to avoid the possible formation of a hydrogen bond between the water and the neighbor phosphate unit, and the Keggin archetype, because it would be unrealistic for a POM structure surrounded by solvent water molecules, as shown in Figure 5.

The computed geometry parameters are summarized and compared with the experimental values in Table 2. Both polyanions present a distorted octahedral geometry around the Co active site, with a quadruplet in the ground state, where the three unpaired electrons are localized in the Co atom. (a) CoP

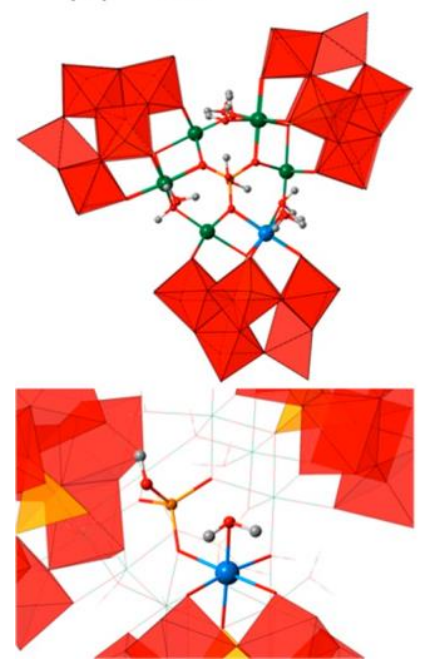

(b) $\mathrm{CoGe}$

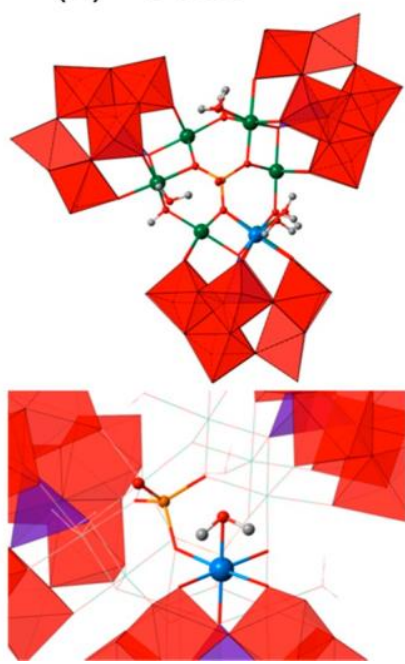

Figure 5. Structures of the optimized models: (a) CoP and (b) $\mathrm{CoGe}$. The bottom panels show the details of the local $\mathrm{Co}-\mathrm{OH}_{2}$ catalytic site $\left(\mathrm{WO}_{6}\right.$, red octahedra; $\mathrm{PO}_{4}$, yellow tetrahedra; $\mathrm{GeO}_{4}$, purple tetrahedra; Co, sky blue; $\mathrm{Zn}$, green; $\mathrm{P}$, yellow; $\mathrm{O}$, red; $\mathrm{H}$, gray). 
Table 2. Calculated and Experimental Co-O Bond Distances (in angstroms), O-Co-O Angles (in degrees), and Mulliken Spin Densities (in $|\mathrm{e}|$ )

$\begin{array}{llllcc} & & d\left(\mathrm{Co}_{-} \mathrm{O}_{\mathrm{t}}^{\mathrm{a}}\right) & \mathrm{d}\left(\mathrm{Co}-\mathrm{O}_{\mathrm{c}}^{\mathrm{b}}\right) & \mathrm{A}\left(\mathrm{O}_{\mathrm{c}}-\mathrm{Co}-\mathrm{O}_{\mathrm{t}}\right) & \rho(\mathrm{Co}) \\ \mathrm{CoP} & \text { computed } & 2.25 & 2.21 & 172.4 & 2.74 \\ & \text { experimental } & 2.14-2.19 & 2.18-2.27 & 174.1-177.3 & 3.00^{\mathrm{c}} \\ \mathrm{CoGe} & \text { computed } & 2.35 & 2.05 & 168.3 & 2.76 \\ & \text { experimental } & 2.11-2.17 & 2.08-2.14 & 174.6-177.4 & 3.00^{\mathrm{c}}\end{array}$

${ }^{a} \mathrm{O}_{\mathrm{t}}$ is the terminal oxygen. ${ }^{\mathrm{b}} \mathrm{O}_{\mathrm{c}}$ is the central oxygen. ${ }^{\mathrm{c}} \mathrm{Spin}$ density associated with the ideal three unpaired electrons at the Co(II) center.

Computed structural data present the typical size expansion compared with the X-ray data in the solid state. ${ }^{22}$ CoGe presents a larger bond distance $(2.35 \AA)$ between the Co and the oxygen of the water ligand $\left(\mathrm{Co}-\mathrm{O}_{\mathrm{t}}\right)$ than in the case of the CoP polyanion $(2.25 \AA)$. This feature is consistent with the shorter $\mathrm{Co}-$ central oxygen bond distance $\left(\mathrm{Co}-\mathrm{O}_{\mathrm{c}}\right)$ found in CoGe $(2.05 \AA)$ in comparison with that obtained for CoP $(2.21 \AA)$. Note that the computed values of the $\mathrm{Co}-\mathrm{O}_{\mathrm{c}}$ distance follow the same trend as the experimental values, whereas the difference between the computed $\mathrm{Co}-\mathrm{O}_{\mathrm{t}}$ values is not observed in the X-ray structure.

Close examination of the computed electronic structures reveals an increase in the energy levels of the molecular orbitals of CoGe compared to those found for $\mathrm{CoP}$. As one can see in Figure 6 , in the case of CoP, $\alpha$ and $\beta$ HOMOs are almost
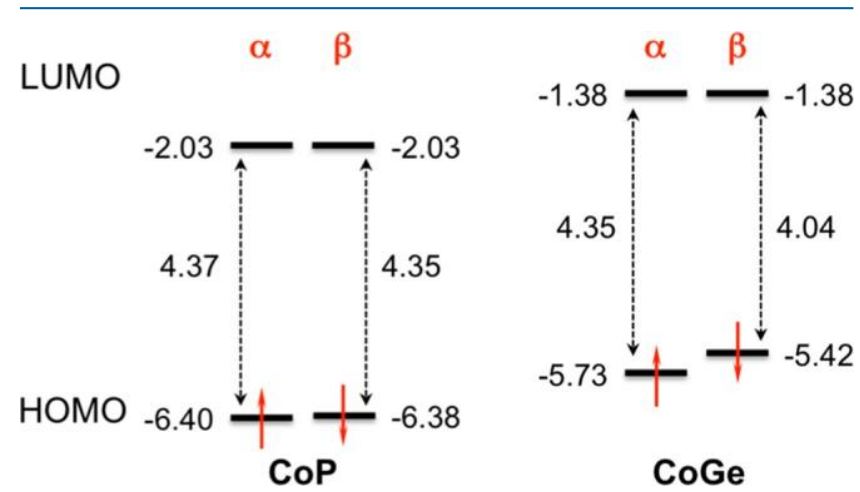

Figure 6. Frontier molecular orbitals of the computed CoP and CoGe structures. The energy values are given in electronvolts.

degenerated, with orbital energies of -6.40 and $-6.38 \mathrm{eV}$, respectively. On the contrary, CoGe shows a computed energy in the $\alpha$ HOMO of $-5.73 \mathrm{eV}$, whereas the $\beta$ HOMO lies at $-5.42 \mathrm{eV}$. Moreover, these orbitals are more localized in the Co atom in the case of the CoGe polyanion, with weights of $26.8 \%$ at the $\alpha$ and $59.5 \%$ at the $\beta$ HOMO level. For CoP, these weights are decreased to $4.1 \%$ and $23.4 \%$ in the $\alpha$ and $\beta$ HOMO, respectively (see Figure 7). Hence, we can say that the fact that the HOMO levels in CoGe lie higher in energy makes this polyanion easier to oxidize than the CoP one, thus increasing its performance toward water oxidation catalysis, as has been seen experimentally; the overpotential to apply for CoGe is somewhat lower than that of CoP. This effect can also be explained with the anion charge effect introduced by Pope. ${ }^{\text {la }}$ The redox properties of a POM depend, among other factors, on the electron charge density, which can be estimated by the $q / m$ ratio, where $q$ is the overall negative charge of the anion and $\mathrm{m}$ is the number of metal atoms present in the structure. ${ }^{21}$ The $\mathrm{q} / \mathrm{m}$ ratio for $\mathrm{CoP}$ is 0.44 , whereas $\mathrm{CoGe}$ has $\mathrm{a} \mathrm{q} / \mathrm{m}$ value of 0.58 , because the negative charge increases from -16 to -21 while the same number of metal centers is

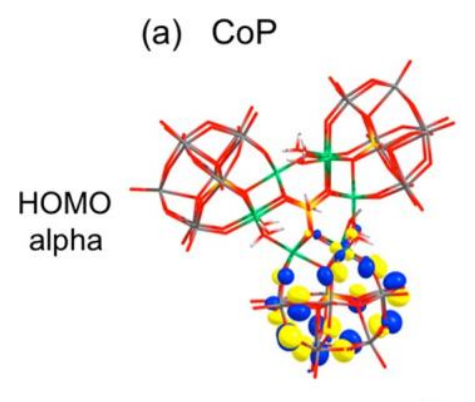

(b) $\mathrm{CoGe}$
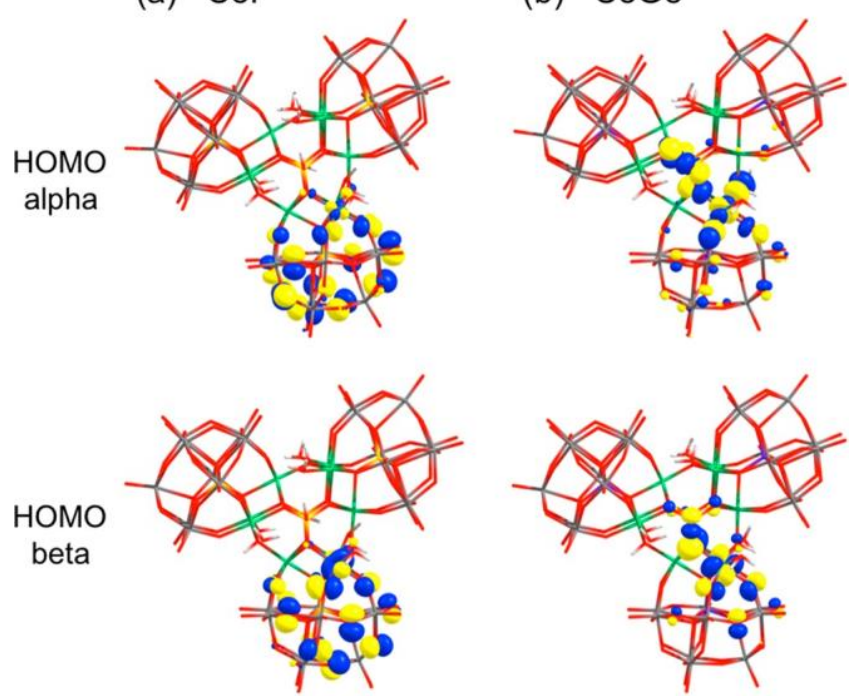

Figure 7. Representation of the $\alpha$ and $\beta$ HOMO for (a) CoP and (b) CoGe.

maintained. Therefore, an increase in the $\mathrm{q} / \mathrm{m}$ ratio leads to a more facile oxidation of the POM, thus boosting its performance as a water oxidation catalyst. We have verified that the frontier orbital energies are not too sensitive for the number of $\mathrm{Zn}^{2+}$ ions introduced in the model used (Table S3).

\section{CONCLUSIONS}

We have successfully synthesized and characterized the germanium analogue $\left[\mathrm{Co}_{9}(\mathrm{OH})_{3}\left(\mathrm{H}_{2} \mathrm{O}\right)_{6}\left(\mathrm{PO}_{4}\right)_{2}(\mathrm{~B}-\alpha-\right.$ $\left.\left.\mathrm{GeW}_{9} \mathrm{O}_{34}\right)_{3}\right]^{21-}$ (1) of the known nonacobalt-containing trimeric, cyclic $\left[\mathrm{Co}_{9}\left(\mathrm{H}_{2} \mathrm{O}\right)_{6}(\mathrm{OH})_{3}\left(\mathrm{HPO}_{4}\right)_{2}(\mathrm{~B}-\mathrm{\alpha}-\right.$ $\left.\left.\mathrm{PW}_{9} \mathrm{O}_{34}\right)_{3}\right]^{16-}\left(\mathrm{Co}_{9}-\mathrm{P}\right)$. Polyanion 1 comprises a cationic $\left\{\mathrm{Co}_{9}(\mathrm{OH})_{3}\left(\mathrm{H}_{2} \mathrm{O}\right)_{6}\left(\mathrm{PO}_{4}\right)_{2}\right\}^{9+}$ core stabilized by three [B- $\alpha-$ $\left.\mathrm{GeW}_{9} \mathrm{O}_{34}\right]^{10-}$ units. The hydrated mixed sodium-cesium salt of 1 was investigated in the solid state by single-crystal X-ray diffraction, FT-IR spectroscopy, as well as thermogravimetric and elemental analyses. Magnetic studies confirmed that the substitution of $\mathrm{P}$ by $\mathrm{Ge}$ does not affect the oxidation state of $\mathrm{Co}^{\mathrm{II}}$ or the magnetic coupling. Furthermore, we have demonstrated that polyanion 1 is a true WOC with a performance that is better than that of $\mathrm{Co}_{9}-\mathrm{P}$. The results were further supported by computational DFT analysis, which attributed the enhanced catalytic behavior of 1 to an increase in the energy levels of the molecular orbitals caused by an increase in the negative charge density on 1 versus $\mathrm{Co}_{9}-\mathrm{P}$. 


\section{ASSOCIATED CONTENT}

\section{Supporting Information}

The Supporting Information is available free of charge on the ACS Publications website at DOI: 10.1021/acs.inorgchem.9b01495.

X-ray crystallographic table, IR spectra, TGA curves, and additional magnetism figures (PDF)

\section{Accession Codes}

CCDC 1916667 contains the supplementary crystallographic data for this paper. These data can be obtained free of charge via www.ccdc.cam.ac.uk/data_request/cif, or by emailing data_request@ccdc.cam.ac.uk, or by contacting The Cambridge Crystallographic Data Centre, 12 Union Road, Cambridge CB2 1EZ, UK; fax: +44 1223336033.

\section{AUTHOR INFORMATION}

\section{Corresponding Authors}

*E-mail: u.kortz@jacobs-university.de. Fax: (+49)421-2003229.

${ }^{\star}$ E-mail: josepmaria.poblet@urv.cat.

*E-mail: jrgalan@iciq.es.

\section{ORCID}

Jorge J. Carbo: 0000-0002-3945-6721

Josep M. Poblet: 0000-0002-4533-0623

Jose Ramón Galan-Mascaros: 0000-0001-7983-9762

Ulrich Kortz: 0000-0002-5472-3058

\section{Present Addresses}

\#A.H.: Department of Chemistry, Quaid-i-Azam University, 45320 Islamabad, Pakistan.

${ }^{\circledR}$ M.I.: Institute of Nanotechnology, Karlsruhe Institute of Technology (KIT), Hermann-von-Helmholtz Platz 1, 76344 Eggenstein-Leopoldshafen, Germany.

Notes

The authors declare no competing financial interest.

\section{ACKNOWLEDGMENTS}

U.K. thanks the German Science Foundation (DFG, KO 2288/20-1), the CMST COST Action CM1203 (PoCheMoN), and Jacobs University for research support. A.H. thanks DAAD for a doctoral fellowship. This work was also supported by the MINECO (Grant CTQ2017-87269-P) and by the Generalitat de Catalunya (Grant 2017SGR-629). J.M.P. thanks the ICREA foundation for an ICREA AWARD for research excellence. Figure 1 was generated with Diamond, version 3.2 (copyright Crystal Impact GbR).

\section{REFERENCES}

(1) (a) Pope, M. T. Heteropoly and Isopoly Oxometalates; Springer: Berlin, 1983. (b) Cronin, L. In Comprehensive Coordination Chemistry II; McCleverty, J. A., Meyer, T. J., Eds.; Elsevier: Amsterdam, 2004; Vol. 7, pp 1-56. (c) Pope, M. T.; Kortz, U. Polyoxometalates. Encyclopedia of Inorganic and Bioinorganic Chemistry; John Wiley \& Sons, Ltd.: Hoboken, NJ, 2012.

(2) (a) Pope, M. T.; Müller, A. Polyoxometalate Chemistry: An Old Field with New Dimensions in Several Disciplines. Angew. Chem., Int. Ed. Engl. 1991, 30, 34-48. (b) Hill, C. L.; Prosser-McCartha, C. M. Homogeneous Catalysis by Transition Metal Oxygen Anion Clusters. Coord. Chem. Rev. 1995, 143, 407-455. (c) Hill, C. L., Ed. Chemical Reviews; American Chemical Society: Washington, DC, 1998; Vol. 98, pp 1-390 (special issue on polyoxometalates). (d) Muller, A.; Roy, S. En Route From the Mystery of Molybdenum Blue via Related Manipulatable Building Blocks to Aspects of Materials Science. Coord.
Chem. Rev. 2003, 245, 153-166. (e) Hill, C. L. Progress and challenges in Polyoxometalate-Based Catalysis and Catalytic Materials Chemistry. J. Mol. Catal. A: Chem. 2007, 262, 2-6. (f) Hasenknopf, B.; Micoine, K.; Lacote, E.; Thorimbert, S.; Malacria, M.; Thouvenot, R. Chirality in Polyoxometalate Chemistry. Eur. J. Inorg. Chem. 2008, 2008,5001-5013. (g) Kortz, U.; Muller, A.; van Slageren, J.; Schnack, J.; Dalal, N. S.; Dressel, M. Polyoxometalates: Fascinating Structures, Unique Magnetic Properties. Coord. Chem. Rev. 2009, 253, 23152327. (h) Kortz, U., Ed. European Journal of Inorganic Chemistry; Wiley, 2009; Vol. 34 (issue dedicated to polyoxometalates). (i) Long, D. L.; Tsunashima, R.; Cronin, L. Polyoxometalates: Building Blocks for Functional Nanoscale Systems. Angew. Chem., Int. Ed. 2010, 49, 1736-1758. (j) Izarova, N. V.; Pope, M. T.; Kortz, U. Classical/NonClassical Polyoxometalate Hybrids. Angew. Chem., Int. Ed. 2012, 51, 9492-9510. (k) Cronin, L., Muller, A., Eds. Chemical Society Reviews; Royal Society of Chemistry, 2012; Vol. 41, pp 7325-7648 (special issue on polyoxometalates).

(3) (a) Geletii, Y. V.; Botar, B.; Kögerler, P.; Hillesheim, D. A.; Musaev, D. G.; Hill, C. L. An All-Inorganic, Stable, and Highly Active Tetraruthenium Homogeneous Catalyst for Water Oxidation. Angew. Chem., Int. Ed. 2008, 47, 3896-3899. (b) Sartorel, A.; Carraro, M.; Scorrano, G.; De Zorzi, R.; Geremia, S.; McDaniel, N. D.; Bernhard, S.; Bonchio, M. Polyoxometalate Embedding of a Tetraruthenium(IV)-Oxo-Core by Template-Directed Metalation of $\left[\mathrm{Y}-\mathrm{SiW}_{10} \mathrm{O}_{36}\right]^{8-}$ : A Totally Inorganic Oxygen-Evolving Catalyst. J. Am. Chem. Soc. 2008, 130, 5006-5007. (c) Sartorel, A.; Miro, P.; Salvadori, E.; Romain, S.; Carraro, M.; Scorrano, G.; Di Valentin, M.; Llobet, A.; Bo, C.; Bonchio, M. Water Oxidation at a Tetraruthenate Core Stabilized by Polyoxometalate Ligands: Experimental and Computational Evidence to Trace the Competent Intermediates. J. Am. Chem. Soc. 2009, 131, 16051-16053. (d) Geletii, Y. V.; Besson, C.; Hou, Y.; Yin, Q.; Musaev, D. G.; Quinonero, D.; Cao, R.; Hardcastle, K. I.; Proust, A.; Kögerler, P.; Hill, C. L. Structural, Physicochemical, and Reactivity Properties of an All-Inorganic, Highly Active Tetraruthenium Homogeneous Catalyst for Water Oxidation. J. Am. Chem. Soc. 2009, 131, 17360-17370. (e) Cao, R.; Ma, H.; Geletii, Y. V.; Hardcastle, K. I.; Hill, C. L. Structurally Characterized Iridium(III)Containing Polytungstate and Catalytic Water Oxidation Activity. Inorg. Chem. 2009, 48, 5596-5598. (f) Besson, C.; Huang, Z.; Geletii, Y. V.; Lense, S.; Hardcastle, K. I.; Musaev, D. G.; Lian, T.; Proust, A.; Hill, C. L. $\mathrm{Cs}_{9}\left[\left(\mathrm{\gamma}-\mathrm{PW}_{10} \mathrm{O}_{36}\right)_{2} \mathrm{Ru}_{4} \mathrm{O}_{5}(\mathrm{OH})\left(\mathrm{H}_{2} \mathrm{O}\right)_{4}\right]$, A New Allinorganic, Soluble Catalyst for the Efficient Visible-Light-Driven Oxidation of Water. Chem. Commun. 2010, 46, 2784-2786. (g) Orlandi, M.; Argazzi, R.; Sartorel, A.; Carraro, M.; Scorrano, G.; Bonchio, M.; Scandola, F. Ruthenium Polyoxometalate Water Splitting Catalyst: Very Fast Hole Scavenging from Photogenerated Oxidants. Chem. Commun. 2010, 46, 3152-3154. (h) Puntoriero, F.; La Ganga, G.; Sartorel, A.; Carraro, M.; Scorrano, G.; Bonchio, M.; Campagna, S. Photo-Induced Water Oxidation with Tetra-Nuclear Ruthenium Sensitizer and Catalyst: A Unique $4 \times 4$ Ruthenium Interplay Triggering High Efficiency with Low-Energy Visible Light. Chem. Commun. 2010, 46, 4725-4727. (i) Toma, F. M.; Sartorel, A. S.; Iurlo, M.; Carraro, M.; Parisse, P.; Maccato, C.; Rapino, S.; Gonzalez, B. R.; Amenitsch, H.; da Ros, T.; Casalis, L.; Goldoni, A.; Marcaccio, M.; Scorrano, G.; Scoles, G.; Paolucci, F.; Prato, M.; Bonchio, M. Efficient Water Oxidation at Carbon NanotubePolyoxometalate Electrocatalytic Interfaces. Nat. Chem. 2010, 2, 826-831. (j) Guo, S. X.; Liu, Y.; Lee, C. Y.; Bond, A. M.; Zhang, J.; Geletii, Y. V.; Hill, C. L. Graphene-supported $\left[\left\{\mathrm{Ru}_{4} \mathrm{O}_{4}(\mathrm{OH})_{2}\left(\mathrm{H}_{2} \mathrm{O}\right)_{4}\right\}\left(\mathrm{Y}-\mathrm{SiW}_{10} \mathrm{O}_{36}\right)_{2}\right]^{10-}$ for Highly Efficient Electrocatalytic Water Oxidation. Energy Environ. Sci. 2013, 6, 26542663.

(4) (a) Yin, Q.; Tan, J. M.; Besson, C.; Geletii, Y. V.; Musaev, D. G.; Kuznetsov, A. E.; Luo, Z.; Hardcastle, K. I.; Hill, C. L. A Fast Soluble Carbon-Free Molecular Water Oxidation Catalyst Based on Abundant Metals. Science 2010, 328, 342-345. (b) Huang, Z.; Luo, Z.; Geletii, Y. V.; Vickers, J. W.; Yin, Q.; Wu, D.; Hou, Y.; Ding, Y.; Song, J.; Musaev, D. G.; Hill, C. L.; Lian, T. Efficient Light-Driven CarbonFree Cobalt-Based Molecular Catalyst for Water Oxidation. J. Am. 
Chem. Soc. 2011, 133, 2068-2071. (c) Sartorel, A.; Truccolo, M.; Berardi, S.; Gardan, M.; Carraro, M.; Toma, F. M.; Scorrano, G.; Prato, M.; Bonchio, M. Oxygenic Polyoxometalates: a New Class of Molecular Propellers. Chem. Commun. 2011, 47, 1716-1718. (d) Stracke, J. J.; Finke, R. G. Electrocatalytic Water Oxidation Beginning with the Cobalt Polyoxometalate $\left[\mathrm{Co}_{4}\left(\mathrm{H}_{2} \mathrm{O}\right)_{2}\left(\mathrm{PW}_{9} \mathrm{O}_{34}\right)_{2}\right]^{10-}$ : Identification of Heterogeneous CoOx as the Dominant Catalyst. J. Am. Chem. Soc. 2011, 133, 14872-14875. (e) Natali, M.; Berardi, S.; Sartorel, A.; Bonchio, M.; Campagna, S.; Scandola, F. Is $\left[\mathrm{Co}_{4}\left(\mathrm{H}_{2} \mathrm{O}\right)_{2}\left(\mathrm{\alpha}-\mathrm{PW}_{9} \mathrm{O}_{34}\right)_{2}\right]^{10-}$ a Genuine Molecular Catalyst in Photochemical Water Oxidation? Answers from TimeResolved Hole Scavenging Experiments. Chem. Commun. 2012, 48, 8808-8810. (f) Goberna-Ferron, S.; Vigara, L.; Soriano-Lopez, J.; Galan-Mascaros, J. R. Identification of a Nonanuclear $\left\{\mathrm{Co}_{9}{ }_{9}\right\}$ Polyoxometalate Cluster as a Homogeneous Catalyst for Water Oxidation. Inorg. Chem. 2012, 51, 11707-11715. (g) Zhu, G.; Geletii, Y. V.; Kögerler, P.; Schilder, H.; Song, J.; Lense, S.; Zhao, C.; Hardcastle, K. I.; Musaev, D. G.; Hill, C. L. Water Oxidation Catalyzed by a New Tetracobalt-Substituted Polyoxometalate Complex: $\left[\left\{\mathrm{Co}_{4}(\mu-\mathrm{OH})\left(\mathrm{H}_{2} \mathrm{O}\right)_{3}\right\}\left(\mathrm{Si}_{2} \mathrm{~W}_{19} \mathrm{O}_{70}\right)\right]^{11-}$. Dalton Trans. 2012, 41, 2084-2090. (h) Evangelisti, F.; Car, P. E.; Blacque, O.; Patzke, G. R. Photocatalytic Water Oxidation with Cobalt-Containing Tungstobismutates: Tuning the Metal Core. Catal. Sci. Technol. 2013, 3, 3117-3129. (i) Song, F.; Ding, Y.; Ma, B.; Wang, C.; Wang, Q.; $\mathrm{Du}$, X.; Fu, S.; Song, J. $\mathrm{K}_{7}\left[\mathrm{Co}^{\mathrm{III}} \mathrm{Co}^{\mathrm{II}}\left(\mathrm{H}_{2} \mathrm{O}\right) \mathrm{W}_{11} \mathrm{O}_{39}\right]$ : A Molecular Mixed-Valence Keggin Polyoxometalate Catalyst of High Stability and Efficiency for Visible Light-Driven Water Oxidation. Energy Environ. Sci. 2013, 6, 1170-1184. (j) Vickers, J. W.; Lv, H.; Sumliner, J. M.; Zhu, G.; Luo, Z.; Musaev, D. G.; Geletii, Y. V.; Hill, C. L. Differentiating Homogeneous and Heterogeneous Water Oxidation Catalysis: Confirmation that $\left[\mathrm{Co}_{4}\left(\mathrm{H}_{2} \mathrm{O}\right)_{2}\left(\alpha-\mathrm{PW}_{9} \mathrm{O}_{34}\right)_{2}\right]^{10-}$ Is a Molecular Water Oxidation Catalyst. J. Am. Chem. Soc. 2013, 135, 14110-14118. (k) Soriano-Lopez, J.; Goberna-Fẹron, S.; Vigara, L.; Carbo, J. J.; Poblet, J. M.; Galan-Mascaros, J. R. Cobalt Polyoxometalates as Heterogeneous Water Oxidation Catalysts. Inorg. Chem. 2013, 52, 4753-4755. (l) Stracke, J. J.; Finke, R. G. Water Oxidation Catalysis Beginning with $\mathrm{Co}_{4}\left(\mathrm{H}_{2} \mathrm{O}\right)_{2}\left(\mathrm{PW}_{9} \mathrm{O}_{34}\right)_{2}{ }^{10-}$ When Driven by the Chemical Oxidant Ruthenium(III)tris(2,2'bipyridine): Stoichiometry, Kinetic, and Mechanistic Studies En Route to Identifying the True Catalyst. ACS Catal. 2014, 4, 79-89. (m) Stracke, J. J.; Finke, R. G. Water Oxidation Catalysis Beginning with $2.5 \mu \mathrm{M}\left[\mathrm{Co}_{4}\left(\mathrm{H}_{2} \mathrm{O}\right)_{2}\left(\mathrm{PW}_{9} \mathrm{O}_{34}\right)_{2}\right]^{10-}$ : Investigation of the True Electrochemically Driven Catalyst at $\geqslant 600 \mathrm{mV}$ Overpotential at a Glassy Carbon Electrode. ACS Catal. 2013, 3, 1209-1219. (n) Schiwon, R.; Klingan, K.; Dau, H.; Limberg, C. Shining Light on Integrity of a Tetracobalt-Polyoxometalate Water Oxidation Catalyst by X-ray Spectroscopy Before and After Catalysis. Chem. Commun. 2014, 50, 100-102. (o) Han, X. B.; Zhang, Z. M.; Zhang, T.; Li, Y. G.; Lin, W.; You, W.; Su, Z. M.; Wang, E. B. Polyoxometalate-Based Cobalt-Phosphate Molecular Catalysts for Visible Light-Driven Water Oxidation. J. Am. Chem. Soc. 2014, 136, 5359-5366. (p) Lv, H.; Song, J.; Geletii, Y. V.; Vickers, J. W.; Sumliner, J. M.; Musaev, D. G.; Kögerler, P.; Zhuk, P. F.; Bacsa, J.; Zhu, G.; Hill, C. L. An Exceptionally Fast Homogeneous Carbon-Free Cobalt-Based Water Oxidation Catalyst. J. Am. Chem. Soc. 2014, 136, 9268-9271. (q) Goberna-Ferron, S.; Soriano-López, J.; GalanMascaros, J. R.; Nyman, M. Solution Speciation and Stability of Cobalt-Polyoxometalate Water Oxidation Catalysts by X-ray Scattering. Eur. J. Inorg. Chem. 2015, 2015, 2833-2840. (r) Folkman, S. J.; Finke, R. G. Electrochemical Water Oxidation Catalysis Beginning with $\mathrm{Co}(\mathrm{II})$ Polyoxometalates: The Case of the Precatalyst $\mathrm{Co}_{4} \mathrm{~V}_{2} \mathrm{~W}_{18} \mathrm{O}_{68}{ }^{10-}$. ACS Catal. 2017, 7, 7-16. (s) Bonchio, M.; Natali, M.; Bazzan, I.; Goberna-Ferron, S.; Al-Oweini, R.; Ibrahim, M.; Bassil, B. S.; Dau, H.; Scandola, F.; Galan-Mascaros, J.; Kortz, U.; Sartorel, A.; Zaharieva, I. Photo-Assisted Water Oxidation by HighNuclearity Cobalt-oxo Cores: Tracing the Catalyst Fate During Oxygen Evolution Turnover. Green Chem. 2017, 19, 2416-2426. (t) Soriano-Lopez, J.; Musaev, D. G.; Hill, C. L.; Galan-Mascaros, J. R.; Carbó, J. J.; Poblet, J. M. Tetracobalt-Polyoxometalate Catalysts for Water Oxidation: Key Mechanistic Details. J. Catal. 2017, 350, 56-63. (u) Folkman, S. J.; Soriano-Lopez, J.; Galan-Mascaros, J. R.; Finke, R. G. Electrochemically Driven Water-Oxidation Catalysis Beginning with Six Exemplary Cobalt Polyoxometalates: Is It Molecular, Homogeneous Catalysis or Electrode-Bound, Heterogeneous CoOx Catalysis. J. Am. Chem. Soc. 2018, 140, 12040-12055. (v) Blasco-Ahicart, M.; Soriano-Lopez, J.; Carbo, J. J.; Poblet, J. M.; Galan-Mascaros, J. R. Polyoxometalate Electrocatalysts Based on Earth Abundant Metals for Efficient Water Oxidation in Acidic Media. Nat. Chem. 2018, 10, 24-30.

(5) (a) Biboum, R. N.; Njiki, C. P. N.; Zhang, G.; Kortz, U.; Mialane, P.; Dolbecq, A.; Mbomekalle, I. M.; Nadjo, L.; Keita, B. High Nuclearity $\mathrm{Ni} / \mathrm{Co}$ Polyoxometalates and Colloidal $\mathrm{TiO}_{2}$ Assemblies as Efficient Multielectron Photocatalysts under Visible or Sunlight Irradiation. J. Mater. Chem. 2011, 21, 645-650. (b) Al-Oweini, R.; Sartorel, A.; Bassil, B. S.; Natali, M.; Berardi, S.; Scandola, F.; Kortz, U.; Bonchio, M. Photocatalytic Water Oxidation by a Mixed-Valent $\mathrm{Mn}(\mathrm{III})_{3} \mathrm{Mn}(\mathrm{IV}) \mathrm{O}_{3}$ Manganese Oxo Core that Mimics the Natural Oxygen-Evolving Center. Angew. Chem., Int. Ed. 2014, 53, 1118211185. (c) Goberna-Ferron, S.; Soriano-Lopez, J.; Galan-Mascaros, J. R. Activity and Stability of the Tetramanganese Polyanion $\left[\mathrm{Mn}_{4}\left(\mathrm{H}_{2} \mathrm{O}\right)_{2}\left(\mathrm{PW}_{9} \mathrm{O}_{34}\right)_{2}\right]^{10-}$ during Electrocatalytic Water Oxidation. Inorganics 2015, 3, 332-340. (d) Du, X.; Ding, Y.; Song, F.; Ma, B.; Zhao, J.; Song, J. Efficient Photocatalytic Water Oxidation Catalyzed by Polyoxometalate $\left[\mathrm{Fe}_{11}\left(\mathrm{H}_{2} \mathrm{O}\right)_{14}(\mathrm{OH})_{2}\left(\mathrm{~W}_{3} \mathrm{O}_{10}\right)_{2}\left(\alpha-\mathrm{SbW}_{9} \mathrm{O}_{33}\right)_{6}\right]^{27-}$ Based on Abundant Metals. Chem. Commun. 2015, 51, 1392513928. (e) Han, X. B.; Li, Y. G.; Zhang, Z. M.; Tan, H. Q.; Lu, Y.; Wang, E. B. Polyoxometalate-Based Nickel Clusters as Visible LightDriven Water Oxidation Catalysts. J. Am. Chem. Soc. 2015, 137, 5486-5493. (f) Das, S.; Misra, A.; Roy, S. Enhancement of Photochemical Heterogeneous Water Oxidation by a Manganese Based Soft Oxometalate Immobilized on a Graphene Oxide Matrix. New J. Chem. 2016, 40, 994-1003. (g) Lauinger, S. M.; Piercy, B. D.; Li, W.; Yin, Q.; Collins-Wildman, D. L.; Glass, E. N.; Losego, M. D.; Wang, D.; Geletii, Y. V.; Hill, C. L. Stabilization of Polyoxometalate Water Oxidation Catalysts on Hematite by Atomic Layer Deposition. ACS Appl. Mater. Interfaces 2017, 9, 35048-35056.

(6) (a) Lv, H.; Geletii, Y. V.; Zhao, C.; Vickers, J. W.; Zhu, G.; Luo, Z.; Song, J.; Lian, T.; Musaev, D. G.; Hill, C. L. Polyoxometalate Water Oxidation Catalysts and the Production of Green Fuel. Chem. Soc. Rev. 2012, 41, 7572-7589. (b) Streb, C. New Trends in Polyoxometalate Photoredox Chemistry: From Photosensitisation to Water Oxidation Catalysis. Dalton Trans. 2012, 41, 1651-1659. (c) Sartorel, A.; Bonchio, M.; Campagna, S.; Scandola, F. Tetrametallic Molecular Catalysts for Photochemical Water Oxidation. Chem. Soc. Rev. 2013, 42, 2262-2280. (d) Galan-Mascaros, J. R. Water Oxidation at Electrodes Modified with Earth-Abundant Transition-Metal Catalysts. ChemElectroChem 2015, 2, 37-50.

(7) (a) Weakley, T. J. R. The Identification and X-ray Structure of the Diphosphatotris(nonatungstophosphato)nonacobaltate(II) Heteropolyanion. J. Chem. Soc., Chem. Commun. 1984, 1406-1407. (b) Galan-Mascaros, J. R.; Gomez-García, C. J.; Borras-Almenar; Coronado, E. High nuclearity magnetic clusters: Magnetic Properties of a Nine Cobalt Cluster Encapsulated in a Polyoxometalate, $\left[\mathrm{Co}_{9}(\mathrm{OH})_{3}\left(\mathrm{H}_{2} \mathrm{O}\right)_{6}\left(\mathrm{HPO}_{4}\right)_{2}\left(\mathrm{PW}_{9} \mathrm{O}_{34}\right)_{3}\right]^{16-}$. Adv. Mater. 1994, 6, 221-223. (c) Clemente-Leon, M.; Coronado, E.; Gomez-García, C. J.; Mingotaud, C.; Ravaine, S.; Romualdo-Torres, G.; Delhaes, P. Polyoxometalate Monolayers in Langmuir-Blodgett Films. Chem. Eur. J. 2005, 11, 3979-3987.

(8) Herve, G.; Teze, A. Study of $\alpha$ - and $\beta$-Enneatungstosilicates and -germanates. Inorg. Chem. 1977, 16, 2115-2117.

(9) Ibrahim, M.; Haider, A.; Lan, Y.; Bassil, B. S.; Carey, A. M.; Liu, R.; Zhang, G.; Keita, B.; Li, W.; Kostakis, G. E.; Powell, A. K.; Kortz, U. Multinuclear Cobalt(II)-Containing Heteropolytungstates: Structure, Magnetism, and Electrochemistry. Inorg. Chem. 2014, 53, 51795188 .

(10) SAINT; Bruker AXS Inc.: Madison, WI, 2007.

(11) Sheldrick, G. M. A Short History of SHELX. Acta Crystallogr., Sect. A: Found. Crystallogr. 2008, 64, 112-122. 
(12) Sheldrick, G. M. SADABS, Program for Area Detector Adsorption

Correction; University of Göttingen: Göttingen, Germany, 1996.

(13) Sheldrick, G. M. SHELX-97/2013, Program for Solution of Crystal Structures; University of Göttingen: Göttingen, Germany, 1997.

(14) Frisch, M. J.; Trucks, G. W.; Schlegel, H. B.; Scuseria, G. E.; Robb, M. A.; Cheeseman, J. R.; Scalmani, G.; Barone, V.; Mennucci, B.; Petersson, G. A.; Nakatsuji, H.; Caricato, M.; Li, X.; Hratchian, H. P.; Izmaylov, A. F.; Bloino, J.; Zheng, G.; Sonnenberg, J. L.; Hada, M.; Ehara, M.; Toyota, K.; Fukuda, R.; Hasegawa, J.; Ishida, M.; Nakajima, T.; Honda, Y.; Kitao, O.; Nakai, H.; Vreven, T.; Montgomery, J. A., Jr.; Peralta, J. E.; Ogliaro, F.; Bearpark, M.; Heyd, J. J.; Brothers, E.; Kudin, K. N.; Staroverov, V. N.; Kobayashi, R.; Normand, J.; Raghavachari, K.; Rendell, A.; Burant, J. C.; Iyengar, S. S.; Tomasi, J.; Cossi, M.; Rega, N.; Millam, N. J.; Klene, M.; Knox, J. E.; Cross, J. B.; Bakken, V.; Adamo, C.; Jaramillo, J.; Gomperts, R.; Stratmann, R. E.; Yazyev, O.; Austin, A. J.; Cammi, R.; Pomelli, C.; Ochterski, J. W.; Martin, R. L.; Morokuma, K.; Zakrzewski, V. G.; Voth, G. A.; Salvador, P.; Dannenberg, J. J.; Dapprich, S.; Daniels, A. D.; Farkas, Ö.; Foresman, J. B.; Ortiz, J. V.; Cioslowski, J.; Fox, D. J. Gaussian 09, revision A.1; Gaussian, Inc.: Wallingford, CT, 2009.

(15) (a) Lee, C.; Yang, C.; Parr, R. G. Development of the ColleSalvetti Correlation-Energy Formula into a Functional of the Electron Density. Phys. Rev. B: Condens. Matter Mater. Phys. 1988, 37, 785789. (b) Becke, A. D. Density-Functional Thermochemistry. III. The Role of Exact Exchange. J. Chem. Phys. 1993, 98, 5648-5652. (c) Stephens, P. J.; Devlin, F. J.; Chabalowski, C. F.; Frisch, M. J. Ab Initio Calculation of Vibrational Absorption and Circular Dichroism Spectra Using Density Functional Force Fields. J. Phys. Chem. 1994, 98, 11623-11627.

(16) Hay, P. J.; Wadt, W. R. Ab Initio Effective Core Potentials for Molecular Calculations. Potentials for the Transition Metal Atoms Sc to Hg. J. Chem. Phys. 1985, 82, 270-283.

(17) (a) Francl, M. M.; Pietro, W. J.; Hehre, W. J.; Binkley, J. S.; Gordon, M. S.; Defrees, D. J.; Pople, J. A. Self-Consistent Molecular Orbital Methods. XXIII. A Polarization-Type Basis Set for Secondrow Elements. J. Chem. Phys. 1982, 77, 3654-3665. (b) Hehre, W. J.; Ditchfield, R.; Pople, J. A. Self Consistent Molecular Orbital Methods. XII. Further Extensions of Gaussian-Type Basis Sets for Use in Molecular Orbital Studies of Organic Molecules. J. Chem. Phys. 1972, 56, 2257-2261. (c) Hariharan, P. C.; Pople, J. A. The Influence of Polarization Functions on Molecular Orbital Hydrogenation Energies. Theor. Chim. Acta 1973, 28, 213-222.

(18) Cances, E.; Mennucci, B.; Tomasi, J. A New Integral Equation Formalism for the Polarizable Continuum Model: Theoretical Background and Applications to Isotropic and Anisotropic Dielectrics. J. Chem. Phys. 1997, 107, 3032-3041.

(19) Alvarez-Moreno, M.; de Graaf, C.; Lopez, N.; Maseras, F.; Poblet, J. M.; Bo, C. Managing the computational chemistry big data problem: the iochem-BD platform. J. Chem. Inf. Model. 2015, 55, 95103.

(20) Brown, I. D.; Altermatt, D. Bond-Valence Parameters Obtained from a Systematic Analysis of the Inorganic Crystal Structure Database. Acta Crystallogr., Sect. B: Struct. Sci. 1985, 41, 244-247.

(21) Folkman, S. J.; Soriano-Lopez, J.; Galan-Mascaros, J. R.; Finke, R. G. J. Am. Chem. Soc. 2018, 140, 12040.

(22) (a) Lopez, X.; Carbó, J. J.; Bo, C.; Poblet, J. M. Structure, Properties and Reactivity of Polyoxometalates: A Theoretical Perspective. Chem. Soc. Rev. 2012, 41, 7537-7571. (b) Lopez, X.; Miro, P.; Carbó, J. J.; Rodríguez-Fortea, A.; Bo, C.; Poblet, J. M. Current Trends in the Computational Modelling of Polyoxometalates. Theor. Chem. Acc. 2011, 128, 393-404. (c) Lopez, X.; Fernandez, J. A.; Poblet, J. M. Redox Properties of Polyoxometalates: New Insights on the Anion Charge Effect. Dalton Trans. 2006, 1162-1167. 